\title{
Recent Scholarship in the Field of kaläm
}

\author{
Jan Thiele 1 \\ ILC-CCHS, CSIC, Madrid \\ jan.thiele@cchs.csic.es
}

\begin{abstract}
This article reviews recent scholarship on kaläm-theology and attempts to briefly describe some tendencies that appear to be promising for opening new perspective for future work. Scholarship has made significant attempts to transcend previous limitations of the field along the confines of religious communities and scholarly disciplines (theology vs. philosophy) and has extended the geographical scope and timeframe of investigation.
\end{abstract}

Keywords: Islamic theology - kalām - Mu'tazilism - Aš̌arism

\section{INTRODUCTION}

An earlier version of this overview of recent scholarship in the field of kalām (or, more completely, 'ilm al-kaläm) was presented at the Atelier d'historiographie critique organised by the present journal (Paris, 1oth February 2017). It has since then been slightly updated. ${ }^{2}$ The scholarship reviewed here is devoted to a discipline that is often translated as 'theology'. This translation is not entirely wrong, but nevertheless somewhat imprecise: to be sure, the mutakallimūn, that is, the practitioners of the discipline of kalām, actually addressed theological questions. Yet the spectrum of their reflections also included fields that the Western tradition would attribute to the domain of philosophy, including metaphysics and physics, epistemology or ethics. It is therefore not surprising that kalām shares many subjects with falsafa, that is, the heirs of Hellenic philosophy in the Islamicate world.

The second problem of the translation 'theology' is that there are other forms of theology distinct from kalām. They are all subsumed under the label ușül al-dìn ('principles of religion'). The reason for there being various forms of theology was that theologians were divided over the appropriate and legitimate methodology for addressing theological problems. The starting point of kalām was rational reflection-as opposed to their detractors, whose departing point was scripture. The latter group of opponents to

1 I gratefully acknowledge funding from the Spanish Government's Ramón y Cajal programme (RYC-2015-18346).

2 The presentation covered works published during the five years before the meeting. I have added some studies that were published since then. 
kalām were primarily found in the milieu of the Traditionalists, and more specifically the Hanbalites. ${ }^{3}$ This is at least what the general picture looks like. The historical reality is however somewhat more complex: more than 35 years ago, D. Gimaret demonstrated, for example, that a thinker like Ibn Taymiyya (d. 728/1328) adopted a very rational approach in his attempts to resolve theological questions. ${ }^{4}$ The same Ibn Taymiyya is a major reference for historical and contemporary Hanbalites. More recently, studies have provided significant additional evidence for the influence of speculative theology on him..$^{5}$ The inclusion of Ibn Taymiyya in an overview of research in kalām is certainly debatable, but omitting him completely would no be less problematic.

This overview of recent research on kaläm is selective. I attempt to briefly describe some tendencies that appear to me promising for opening new perspectives for future work. In addition, I will provide lists of recent contributions to several subfields of kaläm studies. One might blame me for not systematically reviewing recent scholarship on the Māturīdite school, that is the second important movement of Sunni kaläm after Ašcarism. The reason is that I do not feel sufficiently competent to assess the extensive production from Turkey. ${ }^{6}$

3 There were, however, other 'literalists' or 'scripturalists' like, for example, the Zāhirīs.

4 Daniel Gimaret, 'Théories de l'acte humain dans l'école hanbalite', Bulletin d'études orientales vol. 29, 1977, pp. 157-178.

5 See Jon Hoover, Ibn Taymiyya's Theodicy of Perpetual Optimism, Leiden, Brill, 2007; and more recently, Livnat Holtzman, 'Debating the Doctrine of jabr (Compulsion): Ibn Qayyim al-Jawziyya reads Fakhr al-Dīn al-Rāzī', in Birgit Krawietz and Georges Tamer (eds.), Islamic Theology, Philosophy and Law: Debating Ibn Taymiyya and Ibn Qayyim alJawziyya, Berlin/Boston, De Gruyter, 2013, pp. 61-93; Ajhar A. Hakim, 'The Forgotten Rational Thinking in the Hanbalite Thought With Special Reference to Ibn Taymiyya', Journal of Arabic and Islamic Studies vol. 14, 2014, pp. 137-154; Sophia Vasalou, Ibn Taymiyya's Theological Ethics, Oxford, Oxford University Press, 2015; Livnat Holtzman, 'Accused of Anthropomorphism: Ibn Taymiyya's Mihān as Reflected in Ibn Qayyim alJawziyya's al-Käfiya al-Shäfiya', The Muslim World vol. 106, no. 3, 2016, pp. 561-587; Jon Hoover, 'Hanbalī Theology', in Sabine Schmidtke (ed.), The Oxford Handbook of Islamic Theology, Oxford, Oxford University Press, 2016, pp. 625-646; as well as a special issue edited by Caterina Bori and published in The Muslim World vol. 108, no. 1, 2018 (specifically the contributions by R. Adem, 'Ibn Taymiyya as Avicennan? Fourteenth-Century Cosmological Controversies in Damascus', pp. 124-153; F. Griffel, 'Ibn Taymiyya and His Ash'arite Opponents on Reason and Revelation: Similarities, Differences, and a Vicious Circle', pp. 11-39; and J. Hoover and M.A.G. Mahajneh, 'Theology as Translation: Ibn Taymiyya's Fatwa permitting Theology and its Reception into his Averting the Conflict between Reason and Revealed Tradition (Dar' Ta'āruḍ al-'Aql wa l-Naql)', pp. 40-86).

6 I shall therefore limit myself to mentioning the English translation of U. Rudolph's seminal work on the school's eponym al-Māturīdī (Ulrich Rudolph, Al-Māturìdī and the Development of Sunnī Theology in Samarqand, trans. Rodrigo Adem, Leiden, Brill, 2014), 
Readers who would like to keep an eye on future publications in the field are referred to T.-A. Druart's Brief Bibliographical Guides in Medieval Islamic Philosophy and Theology, from which this overview has also greatly benefited. The Brief Bibliographical Guides are hosted at the webpage of the Catholic University of America and are currently in the process of being converted by A. Lammer and P. Adamson into a combined and searchable version, which should be accessible soon via Ludwig-Maximilans-Universität München. ${ }^{7} \mathrm{~A}$ recent attempt to outline the 'state-of-the-art' in the field of the history of Islamic theology, The Oxford Handbook of Islamic Theology, may also serve as a bibliographical guide for research in the field of kalām. ${ }^{8}$

\section{The BEgINNINGS OF KALĀM (2ND-3RD/8TH-9TH CENTURIES)}

In an article published in 1991, D. Gimaret took stock of the achievements in the field of kaläm and deplored an unbalanced focus on the study of the earliest phase of kalamm. ${ }^{9}$ Today the situation appears almost reversed. Since J. van Ess' monumental Theologie und Gesellschaft, ${ }^{10}$ relatively little work has

and such recent publications as Abū Ishāq Ibrāhīm b. Ismāīil al-Ṣaffār al-Buhārī, Talhịṣ al-adilla wa-qawā $c i d$ al-tawhìd, 2 vols., ed. Angelika Brodersen, Beirut, Orient Institut Beirut, 2011; Angelika Brodersen, 'Göttliches und menschliches Handeln im māturīdischen kalām', Jahrbuch für islamische Theologie und Religionspädagogik vol. 2, 2013, pp. 117-139; Angelika Brodersen, 'Das Kapitel über die „schönen Namen Gottes“ im Talhịș aladilla li-qawā'id at-tauhīd des Abū Ishāa as-Ṣaffār al-Buhārī (gest. 534/1139)', Zeitschrift der Deutschen Morgenländischen Gesellschaft vol. 164, no. 2, 2014, pp. 375-406; Angelika Brodersen, Der unbekannte kalām. Theologische Positionen der frühen Māturīdīya am Beispiel der Attributenlehre, Berlin, Lit Verlag, 2014; Nathan Spannaus, 'Šihāb al-Dīn alMarğānī on the Divine Attributes: A Study in Kalām in the 19th Century', Arabica vol. 62, no. 1, 2015, pp. 74-98; Philip Dorroll, 'The Universe in Flux: Reconsidering Abū Manșūr AlMāturīdī's Metaphysics and Epistemology', Journal of Islamic Studies vol. 27, no. 2, 2016, pp. 119-135; Ulrich Rudolph, 'Hanafî Theological Tradition and Māturīdism', in Sabine Schmidtke (ed.), The Oxford Handbook of Islamic Theology, Oxford, Oxford University Press, 2016, pp. 280-296; Nathan Spannaus, 'Theology in Central Asia', in Sabine Schmidtke (ed.), The Oxford Handbook of Islamic Theology, Oxford, Oxford University Press, 2016, pp. 587-6o5; and Thomas Würtz, Islamische Theologie im 14. Jahrhundert. Auferstehungslehre, Handlungstheorie und Schöpfungsvorstellungen im Werk von Sa'd adDìn at-Taftäzānī, Berlin/Boston, De Gruyter, 2016.

7 http://philosophy.cua.edu/faculty/druart/bibliographical-guide.cfm [accessed 24 February 2018].

8 Sabine Schmidtke (ed.), The Oxford Handbook of Islamic Theology, Oxford, Oxford University Press, 2016.

9 Daniel Gimaret, 'Pour un rééquilibrage des études de théologie musulmane', Arabica vol. 38, no. 1, 1991, pp. 11-18.

10 Josef van Ess, Theologie und Gesellschaft im 2. und 3. Jahrhundert Hidschra. Eine Geschichte des religiösen Denkens im frühen Islam, 6 vols., Berlin/New York, de Gruyter, 1991-1997. 
been done on the earliest speculative theologians. An exception is the work of D. Bennett, who wrote his doctoral thesis (University of California 2011) ${ }^{11}$ on one of the most important early mutakallimūn, Ibrāhīm al-Naz̧ạām (d. between $220 / 835$ and $230 / 845$ ) and several shorter papers. ${ }^{12}$ There were some additional studies that returned to older research questions, such as the origins of the dialectical methodology in kaläm, ${ }^{13}$ the Christian contribution to early kalām ${ }^{14}$ and an article that revises the composition history of al-Ašarī's (d. 324/935) Maqālāt, ${ }^{15}$ one of the most important heresiographies of early theology.

The study of early kalām will perhaps receive new impetus: van Ess' work is currently being translated into English and will consequently be accessible to a much wider audience than the original German version. ${ }^{16}$ In addition, the study of early kaläm will most likely benefit from the recent rise of Ibādī studies. W. Madelung and A. Al-Salimi have unearthed some early Ibādī kalām texts, the oldest of which were dated by the editors to the late second/eighth and the early third/ninth century. ${ }^{17}$ Provided they are au-

11 David Bennett, 'The Spirit of Ahypokeimenonical Physics: Another Side of Kalām Natural Philosophy', PhD Thesis, University of California, 2011.

David Bennett, 'Abū Isḥāq al-Nażzām: The Ultimate Constituents of Nature are Simple Properties and Rüh', in Monique Bernards (ed.), Abbasid Studies: Proceedings of the 2010 Meeting of the School of Abbasid Studies, Exeter, Gibb Memorial Trust, 2013, pp. 201-2017; David Bennett, 'The Mu'tazilite Movement (II): The Early Mu'tazilites', in Sabine Schmidtke (ed.), The Oxford Handbook of Islamic Theology, Oxford, Oxford University Press, 2016, pp. 142-158.

13 Naomi Aradi, 'The Origins of the kaläm Model of Discussion on the Concept of tawhìd', Arabic Sciences and Philosophy vol. 23, no. 1, 2013, pp. 135-166; Fedor Benevich, '“Wenn sie sagen..., dann sagen wir...": Die Ursprünge des dialektischen Verfahrens des Kalām', Le Muséon vol. 128, no. 1-2, 2015, pp. 181-201.

14 Fritz W. Zimmermann, 'Kalām and the Greeks', in Behnam Sadeghi et al. (eds.), Islamic Cultures, Islamic Contexts, Leiden, Brill, 2014, pp. 343-363; Orsolya Varsányi, 'The Concept of 'aql in Early Arabic Christian Theology: A Case for the Early Interaction between Philosophy and kalām', in Damien Janos (ed.), Ideas in Motion in Baghdad and Beyond: Philosophical and Theological Exchanges between Christians and Muslims in the Third/ Ninth and Fourth/Tenth Centuries, Leiden, Brill, 2015, pp. 109-134; Sidney H. Griffith, 'Excursus I: Christian Theological Thought during the First 'Abbāsid Century', in Sabine Schmidtke (ed.), The Oxford Handbook of Islamic Theology, Oxford, Oxford University Press, 2016, pp. 91-102.

15 James Weaver, 'A Footnote to the Composition History of Maqālāt al-islämiyyinn: The Internal Parallels in al-Ash'arì's Material on the Shia',Journal of Abbasid Studies vol. 4, no. 2, 2017, pp. 142-186.

16 The first three volumes have already been published: Josef van Ess, Theology and Society in the Second and Third Century of the Hijra, trans. John O'Kane and Gwendolin Goldbloom, Leiden, Brill, 2016-2017. 
thentic, they would be the earliest primary texts of kalām ever discovered. The study of Ibāḍi sources is still in a rudimentary stage, of which a collective volume edited by E. Francesca offers a first outline. ${ }^{18}$ Yet the recent finds of primary sources offer a new textual basis for studying the early phase of kalām.

Abdulrahman Al-Salimi, 'Early Ibāḍī Theological Arguments on Atoms and Accidents', Arabic Sciences and Philosophy vol. 23, no. 1, 2013, pp. 117-134.

Harith Bin Ramli, 'The Predecessors of Ash`arism: Ibn Kullāb, al-Muhāsibī and al-Qalānisi', in Sabine Schmidtke (ed.), The Oxford Handbook of Islamic Theology, Oxford, Oxford University Press, 2016, pp. 215-224.

Patricia Crone, 'Al-Jāḥiz on aṣhāa al-jahālāt and the Jahmiyya', in Rotraud Hansberger, M. Afifi al-Haytham and Charles Burnett (eds.), Medieval Arabic Thought: Essays in Honour of Fritz Zimmermann, London, The Warburg Institute, 2012, pp. 27-40.

Marco Demichelis, 'Fanā' al-Nār Within Early Kalām and Mysticism: An Analysis Covering the Eighth and Ninth Centuries', Archiv Orientální vol. 83, no. 3, 2015, pp. 385-410.

Racha el-Omari, 'The Origins of the Mu'tazila', in Sabine Schmidtke (ed.), The Oxford Handbook of Islamic Theology, Oxford, Oxford University Press, 2016, pp. 130-141.

Nimrod Hurvitz, 'al-Ma'mūn (r. 198/813-218/833) and the Mịnna', in Sabine Schmidtke (ed.), The Oxford Handbook of Islamic Theology, Oxford, Oxford University Press, 2016, pp. 649-659.

Steven C. Judd, 'The Early Qadariyya', in Sabine Schmidtke (ed.), The Oxford Handbook of Islamic Theology, Oxford, Oxford University Press, 2016, pp. 44-54.

Wilferd Madelung, 'Early Ibāḍi Theology', in Sabine Schmidtke (ed.), The Oxford Handbook of Islamic Theology, Oxford, Oxford University Press, 2016, pp. 242-251.

Cornelia Schöck, 'Jahm b. Ṣafwān (d. 128/745-6) and the "Jahmiyya” and Dirār b. 'Amr (d.

'Abd Allāh b. Yazìd al-Fazārī, Leiden, Brill, 2014.

18 Ersilia Francesca (ed.), Ibadi Theology: Rereading Sources and Scholarly Works, Hildesheim, Olms, 2015 (for Ibāọī kalām, see specifically Abdulrahman Al-Salimi, 'Ibāḍism and the Creation of the Qur'ān', pp. 145-155; Moez Dridi, 'The Theology of Human Actions: Imposing the Impossible: al-taklîf and its Problems for the Ibādīis', pp. 177-184; Mohammed Ech-Cheikh, 'Ignored Pages of the History of Ibāḍi Theology in North Africa during the Middle Ages: The Wājiz (Summary) of 'Abf al-Kāfì and the Dalīl (Proof and Demonstration) of Warjalānī', pp. 103-113; Ahmed Ismail, 'The Theory of the Atom in the Ibādī, Ash'arite and Mu'tazilite Schools', pp. 207-221; Douglas Leonard, 'Anthropomorphism of the Divine as Metaphor in Early Ibāḍi Theology and Reformed Calvinism', pp. 199-205; Wilferd Madelung, 'Ibāḍiyya and Mu'tazila: Two Moderate Opposition Movements in Early Islam', pp. 23-28). 
200/815)', in Sabine Schmidtke (ed.), The Oxford Handbook of Islamic Theology, Oxford, Oxford University Press, 2016, pp. 55-80.

Alexander Treiger, 'Origins of Kaläm', in Sabine Schmidtke (ed.), The Oxford Handbook of Islamic Theology, Oxford, Oxford University Press, 2016, pp. 27-43.

\section{STUDIES ON MU'TAZILISM}

From the fifth/eleventh century onwards, the Mu'tazila was increasingly marginalised from Sunni Islam. They were regarded as heretics and their literature was no longer transmitted-and sometimes intentionally destroyed. Our most important sources for the study of the first important school of kaläm are therefore found outside the Sunni realm: on the one hand among the Shiites, and specifically the Zaydìs, and on the other hand in Jewish manuscript sources. ${ }^{19}$

\section{Karaite Sources}

From the late fourth/tenth century onwards, Karaite Jews came to adopt $\mathrm{Mu}$ 'tazilite teachings in their theology. We still possess a substantial corpus

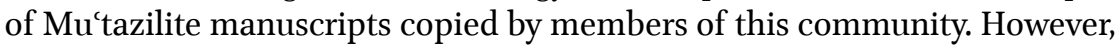
most of these texts were not preserved in their entirety. Rather, they are remnants of the Geniza, that is, store rooms for books that were no longer used. The surviving codices tend to be more or less complete fragments of works. The most important collection of Karaite fragments of Mu'tazilite works is found in the Firkovitch collection in the National Library of Russia,

19 Recently, relatively few works on Mu'tazilism without specific reference to the Shiites or Karaites have been published: see for example Andrew J. Lane, 'You can't tell a book by its author: A study of Mu'tazilite theology in al-Zamakhsharī's (d. 538/1144) Kashshāf', Bulletin of the School of Oriental and African Studies vol. 75, no. 1, 2012, pp. 47-46; Wilferd Madelung, 'Ibn al-Malāhimī on the Human Soul', The Muslim World vol. 102, no. 3-4, 2012, pp. 426-432; Mohd Radhi Ibrahim, 'Immediate Knowledge According to al-Qāḍ̄ 'Abd alJabbār', Arabic Sciences and Philosophy vol. 23, no. 1, 2013, pp. 101-115; Wilferd Madelung, 'Universality in Mu'tazili thought', in Michael Morony (ed.), Universality in Islamic Thought: Rationalism, Science and Religious Belief, London, I.B. Tauris, 2014, pp. 7-21; Hussein Ali Abdulsater, 'Reason, Grace and the Freedom of Conscience: The Period of Investigation in Mu'tazili Theology', Studia Islamica vol. 110, no. 2, 2015, pp. 233-262; Alena Kulinich, 'Beyond theology: Mu'tazilite scholars and their authority in al-Rummānī's tafsir', Bulletin of the School of Oriental and African Studies vol. 78, no. 1, 2015, pp. 135-148; Sabine Schmidtke, 'The Mu'tazilite Movement (III): The Scholastic Phase', in Sabine Schmidtke (ed.), The Oxford Handbook of Islamic Theology, Oxford, Oxford University Press, 2016, pp. 159-180; and the section on Baghdadi Mu'tazilism below. 
St Petersburg. Since these manuscripts were practically unaccessible until the fall of the Soviet Union, the study of this material started only late.

The texts preserved in the Karaite repositories are not necessarily treatises written by members of their community. Rather, they include works by Jewish and Muslim authors. In recent years several valuable critical editions of key texts for the study of Mu'tazilism have been prepared on the basis of Karaite manuscripts. Of significant importance are fragments of the multivolume al-Muginífi abwāb al-tawhìd wa-l-'adl by the Mu'tazilite chief theologian qā d̄ ‘ Abd al-Ğabbār al-Hamadanī (d. 415/1025). The Muġnī is the most important summa of Mu'tazilite teaching that has come down to us. Parts of it were previously accessible in the edition of the fourteen (out of originally twenty) volumes discovered in Yemeni manuscripts. The Karaite fragments recently edited by $\mathrm{O}$. Hamdan and S. Schmidtke contain sections of the work that are not included in the Yemeni recension and were previously believed to be lost. ${ }^{20}$

Additional primary sources that complement the previous finds of $\mathrm{Mu}^{\mathrm{c}}$ tazilite works are two treatises by the Būyid vizir al-Ṣāhib b. 'Abbād (d. 385/995), the patron of $q \bar{a} d \underline{\imath}$ 'Abd al-Ǧabbār. It is again S. Schmidtke who worked on this edition, this time in collaboration with W. Madelung. ${ }^{21}$ The texts are of great interest, despite their relative shortness and their fragmentary character: they are among the most ancient surviving sources of the Bașran school of Mu'tazilism; in addition their thematic focus is specifically relevant to the study of $\mathrm{Mu}$ 'tazilite metaphysics and atomistic ontology. Several recent articles with a more narrow focus shed further light on the Karaite reception of $\mathrm{Mu}$ 'tazilism. Yet the study of the material is still very much in its infancy, and many fragments of works remain unidentified.

Hassan Ansari, Wilferd Madelung and Sabine Schmidtke, 'Yūsuf al-Bașīr's Rebuttal of Abū lHusayn al-Bașrī in a Yemeni Zaydī Manuscript of the 7 th/13th Century', in David Hollenberg, Christoph Rauch and Sabine Schmidtke (eds.), The Yemeni Manuscript Tradition, Leiden, Brill, 2015, pp. 28-65 [also relevant to Zaydī Mu'tazilism].

Bruno Chiesa, 'Some Missing Chapters of al-Qirqisānī's Kitāb al-Anwār Book II', Intellectual History of the Islamicate World vol. 2, no. 1-2, 2014, pp. 37-49.

Yoram Erder, 'The Karaites and Mu'tazilism', in Abdelwahab Meddeb and Benjamin Stora

20 Nukat al-Kitāb al-Mughnī: A Recension of 'Abd al-Jabbār al-Hamadhānīs (d. 415/1025) alMughnī fi abwāb al-tawhìd wa-l-'adl. Al-Kalām fì l-tawlìd; al-Kalām fì l-istițā'a; al-Kalām fì l-taklīf; al-Kalām fì l-nazar wa-l-må̄arif, eds. Omar Hamdan and Sabine Schmidtke, Beirut, Deutsches Orient Institut, 2012.

21 Al-Șạhib Ibn 'Abbād: Promoter of Rational Theology. Two Mu'tazilī kalām Texts from the Cairo Geniza, eds. Wilferd Madelung and Sabine Schmidtke, Leiden, Brill, 2016. 
(eds.), A History of Jewish-Muslim Relations: From the Origins to the Present Day, Princeton, Princeton University Press, 2013, pp. 778-787.

Wilferd Madelung, 'Mu'tazilī Theology in Levi ben Yefet's Kitāb al-Ni'ma', Intellectual History of the Islamicate World vol. 2, no. 1-2, 2014, pp. 9-17.

Sabine Schmidtke, 'Jewish Reception of Twelver Shīī kalām: A Copy of al-Sharīf al-Murtaḍā’s Kitāb al-Dhakhira in the Abraham Firkovitch Collection, St. Petersburg', Intellectual History of the Islamicate World vol. 2, no. 1-2, 2014, pp. 50-74.

Gregor Schwarb, 'Short Communication: A Newly Discovered Fragment of al-Sharīf al-Murtaḍā's K. al-Mulakhkhaṣ fì uṣül al-dìn in Hebrew Script', Intellectual History of the Islamicate World vol. 2, no. 1-2, 2014, pp. 75-79.

David Sklare, 'The Reception of Mu'tazilism among Jews Who Were Not Professional Theologians', Intellectual History of the Islamicate World vol. 2, no. 1-2, 2014, pp. 18-36.

Sarah Stroumsa, 'The Mu'tazila in al-Andalus: The Footprints of a Phantom', Intellectual History of the Islamicate World vol. 2, no. 1-2, 2014, pp. 80-100.

Jan Thiele, 'The Jewish and Muslim Reception of 'Abd al-Jabbār's Kitāb al-Jumal wa-l-uqūd: A Survey of Relevant Sources', Intellectual History of the Islamicate World vol. 2, no. 1-2, 2014, pp. 101-121.

\section{Shiite Mu'tazilism (Zaydīs and Imāmīs)}

The second subfield of Mu'tazilite studies that has seen significant progress is its reception among Shiite theologians. Although the Imāmīs are of some importance, recent scholarship has been specifically productive with respect to Zaydī Mu'tazilism in Iran and Yemen. ${ }^{22}$ As is the case with the study

22 For some recent studies on Imāmī Mu'tazilism see Hassan Ansari and Sabine Schmidtke, The Reception of al-Shaykh al-Țüsìs Theological Writings in 6th/12th century Syria: Facsimile Edition of 'Abd al-Rahmān b. 'Alī b. Muhammad al-Husaynì's Commentary on alṬūs’’s Muqaddama (MS Attı Efendi 1338/ı), Tehran, Mīrāt-i Maktūb, 2013; Hassan Ansari and Sabine Schmidtke, 'Al-Shaykh al-Ṭūis: His writings on Theology and their Reception', in Farhad Daftary and Gurdofarid Miskinzoda (eds.), The Study of Shii Islam: History, Theology and Law, London, I.B. Tauris, 2014, pp. 475-497; Wilferd Madelung, 'Theology: Introduction', in Farhad Daftary and Gurdofarid Miskinzoda (eds.), The Study of Shi ${ }^{i}$ Islam: History, Theology and Law, London, I.B. Tauris, 2014, pp. 455-463; Hassan Ansari and Sabine Schmidtke, 'The Shī‘i Reception of Mu'tazilism (II): Twelver Shīīs', in Sabine Schmidtke (ed.), The Oxford Handbook of Islamic Theology, Oxford, Oxford University Press, 2016, pp. 196-214; Reza Pourjavady and Sabine Schmidtke, 'Twelver Shīī Theology', in Sabine Schmidtke (ed.), The Oxford Handbook of Islamic Theology, Oxford, Oxford University Press, 2016, pp. 456-472; Hussein Ali Abdulsater, 'The Theory of States from alMufîd to al-Murtaḍā', in Saiyad Nizamuddin Ahmad and Sajjad Rizvi (eds.), Philosophy 
of the Karaite-Mu'tazilite textual corpus, the study of Zaydī Mu'tazilism has been advanced primarily on the basis of (previously) unedited manuscript sources. Publications in this field include in-depth studies-either monographs or series of articles - and critical editions, as well as a special issue of Arabica (see below the contributions to vol. 59, no. 3-4). Several individual theologians, like al-Hasan al-Rașșāṣ (d. 584/1188) ${ }^{23}$ or Abū 'Abd Allāh al-'Ansī (d. 667/1269) ${ }^{24}$ have received specific attention. A significant amount of scholarship has focused on the sixth/twelfth and seventh/thirteenth centuries. This period was specifically relevant to the transmission of knowledge and literature from the Iranian Zaydī community to Yemen. ${ }^{25}$ As a result of this process, Yemen became the new cultural and intellectual centre of Zaydism. Some additional studies shed light on later developments and provide insight into the continuity of the Mu'tazilite tradition among the Zaydīs of Yemen. ${ }^{26}$ A recent initiative of the Institute for Advanced Study in Princeton together with the Hill Museum and Manuscript Library (HMML) at Saint John's University, Collegeville, Minnesota attempts to build a comprehen-

and the Intellectual Life in Shĩah Islam, London, The Shi'ah Institute Press, 2017, pp. 1-27.

23 Jan Thiele, Theologie in der jemenitischen Zaydiyya. Die naturphilosophischen Überlegungen des al-Hasan ar-Rașșās, Leiden, Brill, 2013.

24 Hassan Ansari and Sabine Schmidtke, 'Between Aleppo and Șacda: The Zaydī Reception of the Imāmī Scholar Ibn al-Bițrīq al-Hiillì', Journal of Islamic Manuscripts vol. 4, no. 2, 2013, pp. 158-198; Hassan Ansari and Sabine Schmidtke, "The Literary-Religious Tradition among 7 th/13th-Century Yemeni Zaydīs (II): The Case of 'Abd Allāh b. Zayd al-Ansī (d. 667/1269)', in David Hollenberg, Christoph Rauch and Sabine Schmidtke (eds.), The Yemeni Manuscript Tradition, Leiden, Brill, 2015, pp. 101-154; Husām al-Dīn 'Abd Allāh b. Zayd al-Ansī, al-Mahağğg al-bayḍ̄à fì ușūl al-dīn: Facsimile Edition of MS Munich, Bayerische Staatsbibliothek, Cod. arab. 1286, eds. Hassan Ansari and Sabine Schmidtke, Tehran, Mīrāt-i Maktūb/CNRS, 2015.

25 Hassan Ansari and Sabine Schmidtke, 'Mu'tazilism in Rayy and Astarābād: Abū l-Faḍl al'Abbās b. Sharwīn (Studies on the transmission of knowledge from Iran to Yemen in the 6th/12th and 7th/13th C., II)', Studia Iranica vol. 41, no. 1, 2012, pp. 57-100; Hassan Ansari and Jan Thiele, 'MS Berlin, State Library, Glaser 51: A Unique Manuscript from the Early 7th/13th-Century Bahšamite Milieu in Yemen', in David Hollenberg, Christoph Rauch and Sabine Schmidtke (eds.), The Yemeni Manuscript Tradition, Leiden, Brill, 2015, pp. 66-81; Hassan Ansari and Sabine Schmidtke, 'The Cultural Transfer of Zaydī and non-Zaydī Religious Literature from Northern Iran to Yemen (Sixth/Twelfth Century through Eighth/Fourteenth Century)', in Sonja Brentjes and Jürgen Renn (eds.), Globalization of Knowledge in the Post-Antique Mediterranean, London/New York, Routledge, 2016, pp. 141-166.

26 Gregor Schwarb, 'Mu'tazilism in a 2oth century Zaydī Qurān commentary', Arabica vol. 59, no. 3-4, 2012, pp. 372-403; Gregor Schwarb, 'MS Munich, Bavarian State Library, Cod. arab. 1294: A Guide to Zaydī Kalām-Studies during the Țāhirid and Early Qāsimite Periods (Mid-15th to Early 18th Centuries)', in David Hollenberg, Christoph Rauch and Sabine Schmidtke (eds.), The Yemeni Manuscript Tradition, Leiden, Brill, 2015, pp. 155-202. 
sive digital repository of Zaydī manuscripts and is gradually providing open access to a growing corpus of unexplored Mu'tazilite sources. ${ }^{27}$ Recent finds have shown the value of such endeavours: for example, some substantial fragments of Ibn al-Malāḥimī al-Hुwārazmī's Kitāb al-Mu'tamad fi uṣūl alDìn were recently discovered in Zaydī manuscript libraries (Ibn al-Malāḥimī was not a Zaydī, though). These additional portions of texts allowed W. Madelung to publish a new, enlarged edition of the work. ${ }^{28}$

Hassan Ansari, 'Un muhaddit mu'tazilite zaydite : Abū Sa'd al-Sammān al-Rāzī et ses Amālī', Arabica vol. 59, no. 3-4, 2012, pp. 267-29o.

Hassan Ansari, 'Un texte sur la controverse entre les mu'tazilites et les sunnites concernant un musulman qui commet un grand péché et qui meurt sans s'être repenti, composé par 'Alī b. Nāṣir al-Ǧîlānī al-Lāhiǧānī (probablement un savant de à la fin du viie/xiiie s.)', Chroniques du manuscrit au Yémen vol. 20, 2015, pp. 22-56.

Hassan Ansari, 'The Shī̄i Reception of Mu'tazilism (I): Zaydīs', in Sabine Schmidtke (ed.), The Oxford Handbook of Islamic Theology, Oxford, Oxford University Press, 2016, pp. 181-195.

Hassan Ansari, Sabine Schmidtke and Jan Thiele, 'Zaydī Theology in Yemen', in Sabine Schmidtke (ed.), The Oxford Handbook of Islamic Theology, Oxford, Oxford University Press, 2016, pp. 473-493.

Ekaterina Pukhovaia, 'A Zaydī Multitext Manuscript from the Glaser Collection (Staatsbibliothek zu Berlin): MS Glaser 37', Shii Studies Review vol. 1, no. 1-2, 2017, pp. 175-193.

Sulaymān b. 'Abd Allāh al-Hurāšī, Kitāb al-Tafșill li-ğumal al-Tahṣill. Facsimile Edition of MS Berlin, Glaser no. 51. With Introductions and indices by Hassan Ansari and Jan Thiele, Tehran, Mīrāth-e maktūb \& Freie Universität Berlin, 2013.

Sabine Schmidtke, 'Biblical Predictions of the Prophet Muhammad among the Zaydīs of Iran', Arabica vol. 59, no. 3-4, 2012, pp. 218-266.

Sabine Schmidtke, 'Biblical predictions of the Prophet Muḥammad among the Zaydīs of Yemen (6th/12th and 7th/13th centuries)', Orientalia Christiana Analecta vol. 293, 2013, pp. 221-240.

Jan Thiele, 'La causalité selon al-Ḥākim al-Ǧišumī', Arabica vol. 59, no. 3-4, 2012, pp. 291-318.

27 For further details see Sabine Schmidtke, 'Preserving, Studying, and Democratizing Access to the World Heritage of Islamic Manuscripts: The Zaydī Tradition', Chroniques du manuscrit au Yémen vol. 23, 2017, pp. 103-166; Sabine Schmidtke, 'The Zaydi Manuscript Tradition: Virtual Repatriation of Cultural Heritage', International Journal of Middle East Studies vol. 5o, no. 1, 2018, pp. 124-128.

28 Rukn al-Dīn Ibn al-Malāḥimī al-Hূwārazmī, Kitāb al-Mu'tamad fì uṣūl al-dīn, ed. Wilferd Madelung, Tehran, Mīrāt-e Maktūb \& Freie Universität Berlin, 2012. 
Jan Thiele, 'À propos de l'attribution du ms. Ambrosiana ar. F 122, fol. 35b : un fragment d'un texte zaydite du Yémen', Chroniques du manuscrit au Yémen vol. 16, 2013, pp. 16-24.

\section{Abū l-Qāsim al-Ka'bì al-Balhì and the Mu'tazila of Baghdad}

Recent research on kalām has also produced significant work on the Mu'tazilite school of Baghdad and its most prominent representative, Abū l-Qāsim al-Ka'bī al-Balhī (d. 319/931). This branch of Mu'tazilism has long been neglected by scholars of the history of kalamm-for obvious reasons: the sources are quite problematic because they were mostly written by later antagonists and consequently tend to be polemical. The first detailed study on Abū l-Qāsim al-Balhū was eventually published in 2016 by R. el Omari. ${ }^{29}$ Her monograph is the first systematic collection and critical analysis of secondary reports about central elements of the doctrines of this important theologian. Yet el Omari was apparently unaware of the publication of one of Abū l-Qāsim al-Balhī's works in kalām, namely his 'Uyūn al-masāil wa-l-ğa$w \bar{a} b \bar{a} t$, a work she assumed to be lost. ${ }^{30}$ Both the recent edition and el Omari's monograph open important new perspectives for further research.

\section{STUDIES ON AšARISM}

After the decline of Mu'tazilism, Ašcarism became the predominant school of kalām. Its adherents were primarily Šāficites and Mālikites. Scholars widely agree that the history of Ašcarism can be roughly divided into two major phases, and that the transition from the 'methodology of the earlier' to that of the 'later ones' is closely linked to the teaching of the famous Abu Hāmid al-Ġazālī (d. 505/1111). Al-Ġazālī's intellectual activity was a landmark in a longer transformation, to which later theologians, like for instance Fahr al-Dīn al-Rāzì (d. 6o6/121o), also contributed. On the other hand, some innovations previously associated with al-Ġazāli could actually be traced to earlier phases of Ašcarite history. Nonetheless, the periodisation of 'early' (or 'classical') and 'later' Ašcarism is still helpful and will also structure the following outline.

29 Racha el Omari, The Theology of Abū l-Qūsim al-Balkhī/al-Kaćcì (d. 319/931), Leiden, Brill, 2016. See in addition Philippe Vallat, 'Can Man Assess God's Goodness? A Controversy Between Abū Bakr al-Rāzī (d. 925) and Mu'tazilī Theologians', Mélanges de l'Institut Dominicain d'Études Orientales vol. 31, 2015, pp. 213-251.

30 Abū l-Qāsim al-Balhī al-Ka'bī, 'Uyūn al-masā’il wa-l-ğawābāt, eds. Rāğih al-Kurdī, 'Abd alḤamīd al-Kurdī and Hüseyin Hansu, 'Ammān, Dār al-Ḥāmid, 2014. 


\section{Early Ašcarism}

If Ašarism is the most important school of Sunni kalām, this has not saved it from a significant loss of its literature. The majority of the writings of the earliest representatives of Ašarism have not survived. Having said this, it is particularly important that two primary sources of great relevance to the early history of Ašarism have recently been published. The first is an edition of Abū Ğa'far al-Simnānī's (d. 444/1052) al-Bayān 'an uṣūl al-īmān. ${ }^{31}$ The work has survived in a single manuscript and was used extensively by D. Gimaret in his classical 1980 study Théories de l'acte humain en théologie musulmane. ${ }^{32}$ The second publication is a facsimile edition of volume two of the autograph of Nihāyat al-marām $f \grave{\imath}$ dirāyat al-kalām by Fahr al-Dīn alRāzī's (d. 6o6/1210) rather lesser-known father, Diyā' al-Dīn al-Makkī (d. middle of the 6th/12th c.). ${ }^{33}$ Long passages of the Nihãya comprise a recompilation of a work by the author's teacher, namely Abū l-Qāsim al-Anșārī's (d. 512/1118) al-Gunya fi l-kaläm. ${ }^{34}$ Both works are incomplete so that each of them allows a relatively clear idea of the missing parts of the other text. Additional major texts of 'early' Ašcarism have been recently discovered but still wait to be published. However, they have been used in some studies on specific theological issues. Problems that have been dealt with include debates on the 'argument from ignorance' (with specific focus on Abū Bakr alBāqillānī, d. 403/1013, and Abū l-Macālī al-Ǧuwaynī, d. 478/ 1085); ;5 the adoption of Abū Hāšim al-Ğubbā'ī's (d. 321/933) theory of aḥwāl (literally 'states') by Ašcarite theologians; ${ }^{36}$ and al-Bāqillānī's theory of the human act in his Hidāyat al-mustaršidīn. ${ }^{37}$

Abū Ğa'far Muḥammad b. Aḥmad b. Muhạmmad al-Simnānī, al-Bayān 'an uṣūl al-īmān wa-l-kašf 'an tamwīhāt ahl al-țig̀yān, ed. 'Abd al-'Azīz b. Rašīd al-Ayyūb, Kuwait, Dār alDayā', 1435/2014.

32 Daniel Gimaret, Théories de l'acte humain en théologie musulmane, Paris, J. Vrin, 1980.

33 Ḍiyā' al-Dīn al-Makkī, Nihāyat al-marām fì dirāyat al-kalām: Facsimile of the Autograph Manuscript of Vol. II, ed. Ayman Shihadeh, Tehran, Mīrāt-i Maktūb, 2013.

34 Jan Thiele, 'Commonness and Derivative Work in Ašcarite Literature: A Comparison of Diyā’ al-Dīn al-Makkī’s Nihāyat al-marām and Abū al-Qāsim al-Anșārī's al-Ġunya fı alkalām', Mélanges de l'Institut Dominicain d'Études Orientales vol. 32, 2017, pp. 135-166. Ayman Shihadeh, 'The Argument from Ignorance and Its Critics in Medieval Arabic Thought', Arabic Sciences and Philosophy vol. 23, no. 02, 2013, pp. 171-220.

36 Jan Thiele, 'Abū Hāshim al-Jubbā'ī's (d. 321/933) Theory of 'States' (aḥwāl) and its Adaption by Ash'arite Theologians', in Sabine Schmidtke (ed.), The Oxford Handbook of Islamic Theology, Oxford, Oxford University Press, 2016, pp. 364-383 includes some preliminary observations based on al-Bāqillānī's still unedited Hidāyat al-mustaršidīn; Fedor Benevich, 'The Classical Ash'ari Theory of aḥwāl: Juwaynī and his Opponents', Journal of Islamic Studies vol. 27, no. 2, 2016, pp. 136-175, focuses on al-Ğuwaynī.

37 Jan Thiele, 'Conceptions of Self-Determination in Fourth/Tenth-Century Muslim 
Hassan Ansari, 'Sunnism in Rayy during the Seljūq Period: Sources and Observations', Der Islam vol. 93, no. 2, 2016, pp. 46o-471.

Mokdad Arfa Mensia, 'Regards d'Ibn Rushd sur al-Juwaynī: questions de méthode', Arabic Sciences and Philosophy vol. 22, no. 2, 2012, pp. 199-216.

Nazif Muhtaroglu, 'Al-Bāqillānì's Cosmological Argument from Agency', Arabic Sciences and Philosophy vol. 26, no. 2, 2016, pp. 271-289.

Yasir Qadhi, 'Salafi-Ash'arī Polemics of the 3rd \& 4th Islamic Centuries', The Muslim World vol. 106, no. 3, 2016, pp. 433-447.

Ayman Shihadeh, 'Classical Ash`arī Anthropology: Body, Life and Spirit', The Muslim World vol. 102, no. 3-4, 2012, pp. 433-477.

Ayman Shihadeh, 'Theories of Ethical Value in Kalām: A New Interpretation', in Sabine Schmidtke (ed.), The Oxford Handbook of Islamic Theology, Oxford, Oxford University Press, 2016, pp. 384-407 [also relevant to later Ašcarism and Mu'tazilism].

David Thomas, 'Christian Borrowings from Islamic Theology in the Classical Period: The Witness of al-Juwaynī and Abū l-Qāsim al-Anșārī', Intellectual History of the Islamicate World vol. 2, no. 1-2, 2014, pp. 125-142.

Jan Thiele, 'Between Cordoba and Nīsābūr: The Emergence and Consolidation of Ash'arism (Fourth-Fifth/Tenth-Eleventh Century)', in Sabine Schmidtke (ed.), The Oxford Handbook of Islamic Theology, Oxford, Oxford University Press, 2016, pp. 225-241.

\section{Al- Ġazālì}

Al-Ġazālī is not only an exceptional thinker because of his contributions to Muslim intellectual history but also because modern scholarship has devoted numerous publications to him. This should make him one of the best studied figures in Muslim intellectual history. Three recent monograph studies by A. Treiger, A. Cissé and K. Garden show that interest in al-Ġazālī has not decreased. ${ }^{38}$ Al-Ġazālì's 9ooth anniversary in 2011 was the occasion for several collective volumes and special issues of academic journals. ${ }^{39}$ Some

Theology: al-Bāqillānī's Theory of Human Acts in Its Historical Context', Arabic Sciences and Philosophy vol. 26, no. 2, 2016, pp. 245-269.

38 Alexander Treiger, Ispired Knowledge in Islamic Thought: Al-Ghazālì's Theory of Mystical Cognition and its Avicennan Foundation, London/New York, Routledge, 2012; Alphousseyni Cissé, Quelques aspects de la pensée d'Al-Gazālī, Paris, L'Harmattan, 2013; Kenneth Garden, The First Islamic Reviver: Abū Hāmid al-Ghazālī and his Revival of the Religious Sciences, Oxford, Oxford University Press, 2014.

The Muslim World vol. 101, no. 4, 2011 \& vol. 102, no. 1, 2012 (ed. M. Afifi al-Akiti); Mélanges 
new translations of al-Ġazālī's works have also been published, including a partial translation of Ihy $\bar{a}^{3}$ ulüm al-dīn into English ${ }^{40}$ and a translation of Kitāb Asās al-qiyās into Italian. ${ }^{41}$

Maria De Cillis, Free Will and Predestination in Islamic Thought: Theoretical Compromises in the Works of Avicenna, Al-Ghazālī and Ibn 'Arabī, London/New York, Routledge, 2013.

Taneli Kukkonen, 'Receptive to Reality: Al-Ghazālī on the Structure of the Soul', The Muslim World vol. 102, no. 3-4, 2012, pp. 541-561.

Taneli Kukkonen, 'Al-Ghazālī on the Origins of Ethics', Numen vol. 63, no. 2-3, 2016, pp. 271-298.

Edward Omar Moad, 'Al-Ghazali's Position on the "Second Proof" of the "Philosophers" for the Eternity of the World, in the First Discussion of the Incoherence of the Philosophers', Sophia vol. 55, no. 4, 2015, pp. 429-441.

\section{Later Ašarism}

Until recently, the development of Ašcarism after al-Ġazālī and the increasing integration of elements from the Avicennian system of thought during this period went almost unnoticed by experts in kalām. This has greatly changed. Among other researchers, A. Shihadeh has made significant contributions to bringing this era more to the forefront, specifically with his 2006 monograph study on the ethics of the period's most influential thinker, Fahr al-Dīn al-Rāzī. ${ }^{42}$ More recently, A. Shihadeh has further advanced this field and has focused specifically on the interim period between al-Ġazālī and Fahr al-Dīn al-Rāzī and the theologians' increasing engagement with Avicenna. Apart from several article-length studies, ${ }^{43}$ he published a critical

de l'Institut Dominicain d'Études Orientales vol. 30, 2014 (ed. E. Pisani); Ucar Bülent and Frank Griffel (eds.), 9oo Jahre al-Ġazālì im Spiegel der islamischen Wissenschaften, Göttingen, Vandenhoeck \& Ruprecht, 2015; Frank Griffel (ed.), Islam and Rationality: The Impact of al-Ghazāli. Papers Collected at his 9ooth Anniversary, Leiden, Brill, 2016; Georges Tamer (ed.), Islam and Rationality: The Impact of al-Ghazālī. Papers Collected at his gooth Anniversary, Leiden, Brill, 2015.

40 [Abū Hāmid] al-Ghazālī, Kitāb al-'ilm: the Book of Knowledge. Book 1 of the Ihyā' 'ulūm aldin, The revival of the Religious Sciences, trans. Keneth Honerkamp, Louisville, Fons Vitae, 2015 ,

41 [Abū Ḥāmid] al-Ġazālī, Il Kitāb Asās al-qiyās di al-Ǵazālī: Elementi di logica e logica giuridica, trans. Germana Porcasi, Palermo, Officina di Studi Medievali, 2016.

42 Ayman Shihadeh, The Teleological Ethics of Fakhr al-Dīn al-Rāzī, Leiden, Brill, 20o6; see also Ayman Shihadeh, 'From al-Ghazālī to al-Rāzī: 6th/12th Century Developments in Muslim Philosophical Theology', Arabic Sciences and Philosophy vol. 15, no. 1, 2005, pp. 141-179.

Ayman Shihadeh, 'A Post-Ghazālian Critic of Avicenna: Ibn Ghaylān al-Balkhī on the 
edition and comprehensive analysis of an aporetic commentary on Avicenna's Išārāt by Šaraf al-Dīn al-Mas'ūdī (d. before 6o5/1208). ${ }^{44}$ Furthermore, Faḩr al-Dīn al-Rāzī's approach to interpreting the Qur’ān was subject to a monograph study by T. Jaffer. ${ }^{45}$ Finally, Fah̆r al-Dīn al-Rāzì's voluminous Nihāyat al-uqūl has been published. ${ }^{46}$ Various shorter studies have shed light on specific theological and philosophical problems discussed by Fahr al-Dīn al-Rāzī and some post-Rāzian thinkers, as well as on the reception of his thought among the Copts.

Peter Adamson, 'Fakhr al-Dīn al-Rāzī on Place', Arabic Sciences and Philosophy vol. 27, no. 2, 2017, pp. 205-236.

Asad Q. Ahmed, 'The Reception of Avicenna's Theory of Motion in the Twelfth Century', Arabic Sciences and Philosophy vol. 26, no. 2, 2016, pp. 215-243.

Eşref Altaş, 'An Analysis and Editio Princeps of Fakhr al-Dīn al-Rāzìs Risālah: Al-Jawhar alFard', Nazariyat vol. 2, no. 3, 2015, pp. 77-178.

Fedor Benevich, 'The Essence-Existence Distinction: Four Elements of the Post-Avicennian Metaphysical Dispute (11-13th Centuries)', Oriens vol. 45, no. 3-4, 2017, pp. 203-258.

Alnoor Dhanani, 'The Impact of Ibn Sīnā's Critique of Atomism on Subsequent kalām Discussions of Atomism', Arabic Sciences and Philosophy vol. 25, no. 01, 2015, pp. 79-104.

Heidrun Eichner, 'Essence and Existence: Thirteenth-Century Perspectives in Arabic-Islamic Philosophy and Theology', in Dag Nikolaus Hasse and Amos Bertolacci (eds.), The Arabic, Hebrew and Latin Reception of Avicenna's Metaphysics, Berlin/Boston, De Gruyter, 2012, pp. 123-152.

Heidrun Eichner, 'Handbooks in the Tradition of Later Eastern Ash'arism', in Sabine Schmidtke (ed.), The Oxford Handbook of Islamic Theology, Oxford, Oxford University

Materia Medica of the Canon of Medicine', Journal of Islamic Studies vol. 24, no. 2, 2013, pp. 135-174; Ayman Shihadeh, 'Avicenna's Corporeal Form and Proof of Prime Matter in Twelfth-Century Critical Philosophy: Abū l-Barakāt, al-Mas'ūdī and al-Rāzī', Oriens vol. 42, no. 3-4, 2014, pp. 364-396; Ayman Shihadeh, 'Fakhr al-Dīn al-Rāzī's Response to Sharaf al-Dīn al-Mas'ūdī's Critical Commentary on Avicenna's Ishārāt', The Muslim World vol. 104, no. 1-2, 2014, pp. 1-61; Ayman Shihadeh, 'Al-Rāzī's (d. 1210) Commentary on Avicenna's Pointers: The Confluence of Exegesis and Aporetics', in Khaled El-Rouayheb and Sabine Schmidtke (eds.), The Oxford Handbook of Islamic Philosophy, Oxford, Oxford University Press, 2016, pp. 296-325.

44 Ayman Shihadeh, Doubts on Avicenna. A Study and Edition of Sharaf al-Dīn al-Mas'ūdìs Commentary on the Ishārāt, Leiden, Brill, 2015; see also the book review in this issue.

45 Tariq Jaffer, Rāzì: Master of Qur'ānic Interpretation and Theological Reasoning, Oxford, Oxford University Press, 2014.

46 Faḩr al-Dīn al-Rāzī, Nihāyat al-'uqūl fì dirāyat al-ușūl, 4 vols., ed. Sa'īd 'Abd al-Lațîf Fūda, Beirut, Dār al-Dahâāir, 1436/2015. 
Press, 2016, pp. 494-514.

Khaled El-Rouayheb, 'Must God Tell Us the Truth? A Problem in Ash'arī Theology', in Behnam

Sadeghi et al. (eds.), Islamic Cultures, Islamic Contexts, Leiden, Brill, 2014, pp. 411-429 [also relevant for early Aš̌arism \& al-Ġazālī] .

Hannah C. Erlwein, 'Proving God's Existence? A Reassessment of al-Rāzì's Arguments for the Existence of the Creator', Journal of Qur'anic Studies vol. 19, no. 2, 2017, pp. 31-63.

Muammer İskenderoğlu, 'Fakhr al-Dīn al-Rāzī and Ibn 'Arabī on the Ways to Knowledge of God: Unveiling or Reflection and Reasoning?', in John A. Chesworth et al. (eds.), The Character of Christian-Muslim Encounter, Leiden, Brill, 2015, pp. 111-125.

Tarek Ladjal, 'The Development of the Ash'arite Doctrine in North Africa: Building of Theological, Political and Religious Unity', Academic Journal of Interdisciplinary Studies vol. 4, no. 3, 2015, pp. 291-30o.

Andreas Lammer, 'Eternity and Origination in the Works of Sayf al-Dīn al-Āmidī and Athīr alDīn al-Abharī: Two Discussions from the Seventh/Thirteenth Century', The Muslim World vol. 107, no. 3, 2017, pp. 432-481.

Felicitas Opwis, 'Attributing Causality to God's law: The Solution of Fahr ad-Dīn al-Rāzì', in David Reisman and Felicitas Opwis (eds.), Islamic Philosophy, Science, Culture, and Religion: Studies in honor of Dimitri Gutas, Leiden, Brill, 2011, pp. 397-418.

Gregor Schwarb, 'The 13th Century Copto-Arabic Reception of Fakhr al-Dīn al-Rāzī: Al-Rashīd Abū l-Khayr Ibn al-Ṭayib's Risālat al-Bayān al-azhhar fì l-radd 'alā man yaqūlu bi-l-qaḍ̄à wa-l-qadar', Intellectual History of the Islamicate World vol. 2, no. 1-2, 2014, pp. 143-169.

Gregor Schwarb, 'Excursus III: The Coptic and Syriac Receptions of Neo-Ash'arite Theology', in Sabine Schmidtke (ed.), The Oxford Handbook of Islamic Theology, Oxford, Oxford University Press, 2016, pp. 547-566.

Mark N. Swanson, 'Christian Engagement with Islamic kaläm in Late 14th-Century Egypt: The Case of al-Ḥāwī by al-Makīn Jirjis Ibn al-'Amīd "the Younger"', Intellectual History of the Islamicate World vol. 2, no. 1-2, 2014, pp. 214-226.

Hidemi Takahashi, 'Reception of Islamic Theology among Syriac Christians in the Thirteenth Century: The Use of Fakhr al-Dīn al-Rāzī in Barhebraeus' Candelabrum of the Sanctuary', Intellectual History of the Islamicate World vol. 2, no. 1-2, 2014, pp. 170-192.

Philippe Vallat, 'Between Hellenism, Islam, and Christianity: Abū Bakr al-Rāzī and His Controversies with Contemporary Mutazilite Theologians as Reported by the Ash'arite Theologian and Philosopher Fakhr al-Dīn al-Rāzì', in Damien Janos (ed.), Ideas in Motion in Baghdad and Beyond: Philosophical and Theological Exchanges between Christians and Muslims in the Third/Ninth and Fourth/Tenth Centuries, Leiden, Brill, 2015, pp. 
178-220.

Robert Wisnovsky, 'Essence and Existence in the Eleventh- and Twelfth-Century Islamic East (Mašriq): A Sketch', in Dag Nikolaus Hasse and Amos Bertolacci (eds.), The Arabic, Hebrew and Latin Reception of Avicenna's Metaphysics, Berlin/Boston, De Gruyter, 2012, pp. 27-50.

\section{'Regional Manifestations' of Ašcarism}

The growing interest in the developments of Ašcarism after al-Ġazālī shifted the geographical focus onto the Islamic east. It was specifically thinkers from this geographical region —including Faḩr al-Dīn al-Rāzì himself-who contributed to the process that can be described as a synthesis of Ašcarism and post-Avicennian philosophy. Yet some recent works have also focussed a spotlight on the development of Ašarism in other areas, including the Indian subcontinent ${ }^{47}$ and the Islamic west. The study of Maghribi Ašcarism is receiving new stimuli from research activities in the region itself, with some initiatives of individual scholars and institutions specifically dedicated to the study of Maghribi Ašcarism, such as the Markaz Ab̄̄ l-Hasan al-Ašcarī based in the Moroccan city of Tetuan. In addition, large sections of a recent monograph on Islamic intellectual history in the eleventh/seventeenth century by K. El-Rouayheb are devoted to Mālikite Ašcarism in North Africa. ${ }^{48} \mathrm{~A}$. Spevack's book on an Egyptian Ašarite theolgian from the twelfth/eighteenth century further broadens the geographical and temporal perspective of recent approaches. ${ }^{49}$

'Aqūdat Abī Bakr al-Murādī, ed. Ğamāl 'Allāl al-Bahtī, Tetuan, Markaz Abī l-Ḥasan al-Aš̌arī, 1433/2012.

Abū l-Ḥağǧāğ Yūsuf b. Mūsa al-Ḍarīr, al-Tanbīh wa-l-iršād fì 'ilm al-ítiqād, eds. Samīr Qūbī', Muhammad al-'Imrānī and Nūr al-Dīn Šu'aybī, Rabat, Wizārat al-Awqāf wa-l-Šu'ūn alIslāmiyya, 1435/2014.

47 Asad Q. Ahmed and Reza Pourjavady, 'Theology in the Indian Subcontinent', in Sabine Schmidtke (ed.), The Oxford Handbook of Islamic Theology, Oxford, Oxford University Press, 2016, pp. 6o6-624.

48 Khaled El-Rouayheb, Islamic Intellectual History in the Seventeenth Century: Scholarly Currents in the Ottoman Empire and the Maghreb, Cambridge, Cambridge University Press, 2015.

49 Aaron Spevack, The Archetypal Sunni Scholar: Law, Theology, and Mysticism in the Synthesis of al-Bājūrī, New York, SUNY Press, 2014; see also Aaron Spevack, 'Egypt and the Later Ash'arite School', in Sabine Schmidtke (ed.), The Oxford Handbook of Islamic Theology, Oxford, Oxford University Press, 2016, pp. 534-546. 
Ğamāl 'Allāl al-Bahtī (ed.), al-Fikr al-Ašcarì bi-l-Mag̉rib hilāl marhalatay al-ta’sīs wa-l-tarsīm: al-mu’attirāt al-Mašriqiyya wa-l-mahșūṣiyyāt al-maḥalliyya, 2 vols., Tetuan, al-Rābița alMuhammadiyya li-l-'Ulamā’/Markaz Abī l-Ḥasan al-Aš́arī, 1438/2017.

Lutz Berger, 'Interpretations of Ash'arism and Māturīdism in Mamluk and Ottoman Times', in Sabine Schmidtke (ed.), The Oxford Handbook of Islamic Theology, Oxford, Oxford University Press, 2016, pp. 693-703.

Mohamed Bilal-Achmal, 'Textos del legado ašarī magrebí: Al-'aqīda al-burhāniyya al-aš́ariyya de Abū 'Amr al-Salālŷī al-Fāsī', al-Qantara vol. 34, no. 1, 2013, pp. 205-213.

Fahrasat Abī Ğafar Aḥmad b. Yūsuf al-Fihrī al-Lablī, ed. Nūr al-Dīn Šūbad, Tetuan, al-Rābiṭa al-Muḥammadiyya li-l-'Ulamā’/Markaz Abī l-Ḥasan al-Ašarāī, 1434/2013.

Maribel Fierro, 'The Religious Policy of the Almohads', in Sabine Schmidtke (ed.), The Oxford Handbook od Islamic Theology, Oxford, Oxford University Press, 2016, pp. 679-692.

Abū Bakr Muḥammad Ibn al-'Arabī, Kitāb al-Af'āl, ed. Nabīla al-Zikrī, Tetuan, al-Rābiṭa alMuḥammadiyya li-l-'Ulamā'/Markaz Abī l-Ḥasan al-Ash'arī, 2017.

Abū 'Abd Allāh Muḥammad b. Muhammad Ibn 'Arafa, al-Muhtaṣar al-kalāmī, ed. Nizār Ḥammādī, Tunis, Dār al-Imām Ibn 'Arafa, 1435/2014.

Ibrāhīm b. Aḥmad al-Qurašì al-Taymī Ibn Bazīza, al-Is'ād fǐ šarḥ al-Iršād (al-muštamil 'alā qawā'id al-itiqād), eds. 'Abd al-Razzāq Basrūr and 'Imād al-Suhayl, Kuwait, Dār al-Ḍiyā’, 1435/2014.

Ibn Ṭalha al-Yāburī wa-Muhtașaruhu fì uṣūl al-dīn, ed. Muhammad al-Ṭabarānī, Tetuan, Markaz Abī l-Ḥasan al-Aš‘arī, 1434/2013.

Muẓaffar b. 'Abd Allāh al-Miṣrī al-Muqtaraḥ, Šarh al-Iršād fí uṣūl al-i'tiqād, 2 vols., ed. Nazīha Macāriğ, Tetuan, Markaz Abī l-Ḥasan al-Ašcarī, 2014.

M. Sait Özervarll, 'Theology in the Ottoman Lands', in Sabine Schmidtke (ed.), The Oxford Handbook of Islamic Theology, Oxford, Oxford University Press, 2016, pp. 567-586.

Abū 'Abd Allāh Muḥammad b. Yūsuf al-Sanūsī, Talātatat 'aqāì ašariyya, ed. Hูālid Zahrī, Tetuan, Markaz Abī l-Ḥasan al-Ašarī, 1433/2012.

Sabine Schmidtke, 'Ibn Hazm's Sources on Ash'arism and Mu'tazilism', in Maribel Fierro, Camilla Adang and Sabine Schmidtke (eds.), Ibn Hazm of Cordoba. The Life and Works of a Controversial Thinker, Leiden, Brill, 2013, pp. 373-401.

Delfina Serrano Ruano, 'La diffusion de l'ašarisme et la réforme du crédo malikite à l'époque almoravide: Ibn Rušd al-Ǧadd, Abū Bakr Ibn al-'Arabī et le qāọī 'Iyāḍ', in Cyrille Aillet and Bulle Tuil Leonetti (eds.), Dynamiques religieuses et territoires du sacré au Maghreb médiéval: éléments d'enquête, Madrid, CSIC, 2015, pp. 79-102. 
Delfina Serrano, 'Later Ash'arism in the Islamic West', in Sabine Schmidtke (ed.), The Oxford Handbook of Islamic Theology, Oxford, Oxford University Press, 2016, pp. 515-533.

Justin Stearns, “All Beneficial Knowledge is Revealed”: The Rational Sciences in the Maghrib in the age of al-Yūsī (d. 1102/1691)', Islamic Law and Society vol. 21, no. 1-2, 2014, pp. 49-8o.

Jan Thiele, 'Notes sur l'aš‘arisme d'Abū l-Walīd al-Bāğī', in Nejmeddine Hentati (ed.), Ishām alBāğı̀ wa-l-Lahmì fi tațawwur al-madhab al-mālikī/Contribution d'al-Béji et d'al-Lakhmi à l'évolution du malikisme, Tunis, Université Ez-zitouna, 2015, pp. 411-431.

Abū 'Abd Allāh al-Tilimsānī, Kitāb al-Muḥāẹarāt, ed. Ikrām Būlu'ayš, Tetuan, al-Rābiṭa alMuḥammadiyya li-l-'Ulamā’/Markaz Abī l-Ḥasan al-Ašcarī, 2017.

L.W.C. van Lit, 'An Ottoman Commentary Tradition on Ghazālī's Tahāfut al-falāsifa. Preliminary Observations', Oriens vol. 43, no. 3-4, 2015, pp. 368-413.

Rotraud Wielandt, 'Main Trends of Islamic Theological Thought from the Late Nineteenth Century to Present Times', in Sabine Schmidtke (ed.), The Oxford Handbook of Islamic Theology, Oxford, Oxford University Press, 2016, pp. 707-764.

Abū l-Ḥasan 'Alī b. 'Abd al-Raṃān al-Yafran̄̄ al-Ṭanǧī, al-Mabāḥit al-'aqliyya fì šarh máānī al'Aqīda al-burhāniyya, ed. Ǧamāl 'Allāl al-Bahtīi, Tetuan, Markaz Abī l-Ḥasan al-Ašcarī, 2017 .

Huālid Zahrī, al-Mașādir al-Mag̉ribiyya li-l-'aqìda al-Aš́ariyya: bibliyūg̀rāfiyyā wa-dirāsa bibliyūmitriyya, 2 vols., Tetuan, al-Rābiṭa al-Muhammadiyya li-l-'Ulamā’/Markaz Abī l-Ḥasan al-Ašarī, 2017.

\section{CONCLUSION}

In many respects, the 'state-of-the-art' in kalām studies still appears unsatisfactory. A number of desiderata that had been identified already in 1991 by D. Gimaret have only been partially addressed, and a great deal of basic research remains to be done, including the identification and edition of sources that remain in manuscript form. Yet one has to bear in mind that modern research on kaläm is a relatively young field of study and that it has seen significant advances, including contributions that have opened perspectives for future work.

The claim that the study of kalām can and should not be limited to Muslim scholars and their literary production is not entirely new. However, recent scholarship has underscored that non-Muslim sources are indispensable for the field: the fact that we now possess significant new portions of 'Abd al-Ǧabbār's al-Muğnī fi abwāb al-tawhìd wa-l-'adl and even textual fragments from the pen of al-Ṣạ̄ib b. 'Abbād that predate 'Abd al-Ǧabbār are 
just two striking examples from the domain of Mu'tazilite studies. These texts indeed require closer analysis in order to complete and refine our knowledge of Bașran Mu'tazili kalām. As for the Aš́arite school, studies on the Coptic reception of Faḩr al-Dīn al-Rāzì's teaching has also highlighted the relevance of cross-denominational approaches to the study of kaläm.

Scholars have not only challenged the limitations of the field along the confines of religious communities. The appropriateness of sharply distinguishing between theology and philosophy has also become an important issue. Recent scholarship has devoted a great deal of work to studying the synthesis of post-Avicennian philosophy with kalām, specifically with regard to later developments in the Ašcarite school. It is now beyond doubt that later kaläm made a significant contribution to the continuity of falsafa (as opposed to the outdated narrative of the 'decline' of philosophy caused by the attacks of the theologians). The methodological distinction between the 'demonstrative' nature of falsafa and the 'dialectic' (and therefore inferior) nature of kalamm appears no longer tenable in the light of recent research. As a result, surveys of 'Islamic philosophy' increasingly acknowledge the 'philosophical' nature of kalām in general. ${ }^{50}$ This opens new room for further exploring the relationship between kalām and falsafa.

Some significant attempts to 'decentralise' the perspective on kaläm have been made: interest in developments in more 'peripherical' regions like Yemen, Oman or the Maghrib has significantly grown. One might also add the advances in the study of Ottoman kaläm. However, the latter's marginalisation in scholarship of Islamic intellectual history had nothing to do with a geographical periphery but rather with the previously unquestioned narrative of a 'decline' of Islamic thought under the Ottomans. With the widening of the geographical scope, the timeframe of investigation has also been extended. If several years ago the field was specifically concerned with early kalām, the perspective is today much wider than ever before, and important

50 Peter Adamson, 'Arabic Philosophy and Theology before Avicenna', in John Marenbon (ed.), The Oxford Handbook of Medieval Philosophy, Oxford, Oxford University Press, 2012, pp. 58-82; Peter Adamson, Philosophy in the Islamic World: A Very Short Introduction, Oxford, Oxford University Press, 2015; Peter Adamson, Philosophy in the Islamic World: A history of philosophy without any gaps, Volume 3, Oxford, Oxford University Press, 2016; Khaled El-Rouayheb and Sabine Schmidtke (eds.), The Oxford Handbook of Islamic Philosophy, Oxford, Oxford University Press, 2016; Khaled El-Rouayheb, 'Theology and Logic', in Sabine Schmidtke (ed.), The Oxford Handbook of Islamic Theology, Oxford, Oxford University Press, 2016, pp. 408-431; Frank Griffel, 'Theology Engages With Philosophy: al-Ghazālì's Tahāfut al-falāsifa and Ibn al-Malāhimì's Tuhfat al-mutakallimīn $f i$ l-radd 'alā l-falāsifa', in Sabine Schmidtke (ed.), The Oxford Handbook of Islamic Theology, Oxford, Oxford University Press, 2016, pp. 435-455. 
work has been done on periods and trends that were previously considered unworthy of serious investigation. 